\title{
PEMODELAN DINDING GESER BIDANG SEBAGAI ELEMEN KOLOM EKIVALEN PADA GEDUNG BETON BERTULANG BERTINGKAT RENDAH
}

\author{
Yosafat Aji Pranata $^{1}$, Yunizar ${ }^{2}$ \\ ${ }^{1}$ Dosen Biasa, Jurusan Teknik Sipil, Fakultas Teknik, Universitas Kristen Maranatha \\ ${ }^{2}$ Alumnus, Jurusan Teknik Sipil, Fakultas Teknik, Universitas Kristen Maranatha
}

\begin{abstract}
ABSTRAK
Dinding geser didesain sebagai penahan gaya lateral akibat pengaruh gempa. Struktur gedung dengan dinding geser pada umumnya memiliki kinerja yang cukup baik pada saat gempa. Pemodelan dinding geser sebagai elemen kolom ekivalen pada beberapa perangkat lunak yang ada, dapat memberikan manfaat, antara lain untuk kepentingan analisis statik nonlinier (pushover). Tujuan penelitian ini adalah mempelajari pemodelan dinding geser bidang sebagai elemen kolom ekivalen pada studi kasus gedung beton bertulang dengan klasifikasi gedung tidak beraturan. Gedung yang ditinjau berada pada wilayah gempa 3 jenis tanah keras, bertingkat rendah (dua model), dengan acuan peraturan gempa SNI 1726-2002. Hasil penelitian memperlihatkan bahwa $\%$-relatif perbedaan peralihan atap gedung model dinding geser dengan model kolom ekivalen berkisar antara 7,5-78,5\% dan \%-relatif perbedaan gaya geser dasar berkisar antara 0,13-0,58\%. Secara umum dapat disimpulkan bahwa model kolom ekivalen dapat diterapkan sebagai model dinding geser.
\end{abstract}

Kata Kunci: Dinding geser, Kolom ekivalen, Beton bertulang, Kekakuan.

\begin{abstract}
Shearwall was designed to resist lateral load due to earthquake effect. In general, a building with shearwall have a better performance during an earthquake event. Modeling of shearwall as an equivalent column at a several software, give a benefit, for example to modeling nonlinear static analysis (pushover). The objectives of this study are to study modeling of plane shearwall as an equivalent column using case study irregular reinforced concrete buildings. Buildings was designed at zone 3 Indonesian map with hard soil type, low-rise (two model) buildings, in accordance with earthquake code SNI 1726-2002. Results indicated that \%-relative difference of roof displacement between buildings which are designed using shearwall and equivalent column ranged from $7.5-78.5 \%$ and \%-relative difference of base shear force ranged from $0.13-0.58 \%$. In general the equivalent column can be applied as a plane shearwall.
\end{abstract}

Keywords: Shearwall, Equivalent column, Reinforced concrete, Stiffness.

\section{PENDAHULUAN}

Perencanaan gedung bertingkat harus didisain terhadap beban gempa, salah satu caranya adalah dengan menggunakan elemen-elemen struktur kaku berupa dinding geser, dengan penggunaan dinding geser pada struktur bangunan, sebagian besar beban gempa akan terserap oleh dinding geser tersebut.

Tujuan penelitian ini adalah (a). Melakukan pemodelan dan analisis terhadap struktur bangunan gedung beton bertulang tidak beraturan bertingkat rendah dengan menggunakan perangkat lunak ETABS, dimana struktur gedung dimodelkan 2 (dua) cara, 
yaitu model pertama adalah elemen dinding geser menggunakan fitur wall, dan model kedua elemen dinding geser menggunakan fitur kolom ekivalen (frame); dan (b). Membandingkan hasil analisis (statik ekivalen dan dinamik respon spektrum) dengan tinjauan yaitu waktu getar alami, gaya geser dasar, dan peralihan tiap lantai.

Sedangkan ruang lingkup penulisan adalah sebagai berikut: Gedung termasuk dalam kategori tidak beraturan; Gedung terletak di Wilayah Gempa 3 (SNI 02-17262002), tanah keras; Jenis sistem struktur adalah sistem rangka gedung; Beban gempa direncanakan sesuai SNI 02-1726-2002; Analisis menggunakan metode statik ekivalen dan dinamik respon spektrum; dan Model kedua (kolom ekivalen) menggunakan asumsi faktor pengali untuk momen inersia penampangnya dengan model pertama (wall) sebagai tolak ukur.

\section{TINJAUAN LITERATUR}

Kategori gedung diklafikasikan menjadi 3 (tiga) yaitu: gedung bertingkat rendah, bertingkat tinggi, dan bertingkat sangat tinggi. Sesuai FEMA 356 gedung dengan jumlah lantai kurang dari 10 termasuk kategori bertingkat rendah, sedangkan jumlah lantai 10 atau lebih termasuk kategori bertingkat tinggi. Selain 2 (dua) kategori tersebut, Sukamta 2008 memberikan definisi bahwa apabila rasio lebar dibandingkan dengan tinggi gedung lebih besar dari 1 banding 8 maka gedung dapat dikategorikan sangat tinggi (sangat langsing).

Dinding geser adalah dinding beton bertulang dengan kekakuan bidang datar yang sangat besar, yang ditempatkan pada lokasi tertentu (ruang lift atau tangga) untuk menyediakan tahanan gaya / beban horizontal. Dinding geser biasanya dikategorikan berdasarkan geometrinya yaitu:

- $\quad$ Dinding langsing (Flexural wall), yaitu dinding geser yang memiliki rasio $h w / l w \geq$ 2, dimana desain dikontrol oleh prilaku lentur

- $\quad$ Dinding pendek (Squat wall), yaitu dinding geser yang memiliki rasio $h w / l w \leq 2$, dimana desain dikontrol oleh perilaku geser

- $\quad$ Dinding berangkai (Coupled shear wall), dimana momen guling yang terjadi akibat beban gempa ditahan oleh sepasang dinding, yang dihubungkan oleh balok-balok perangkai, sebagai gaya-gaya tarik dan tekan yang bekerja pada masing-masing dasar pasangan dinding tersebut. 

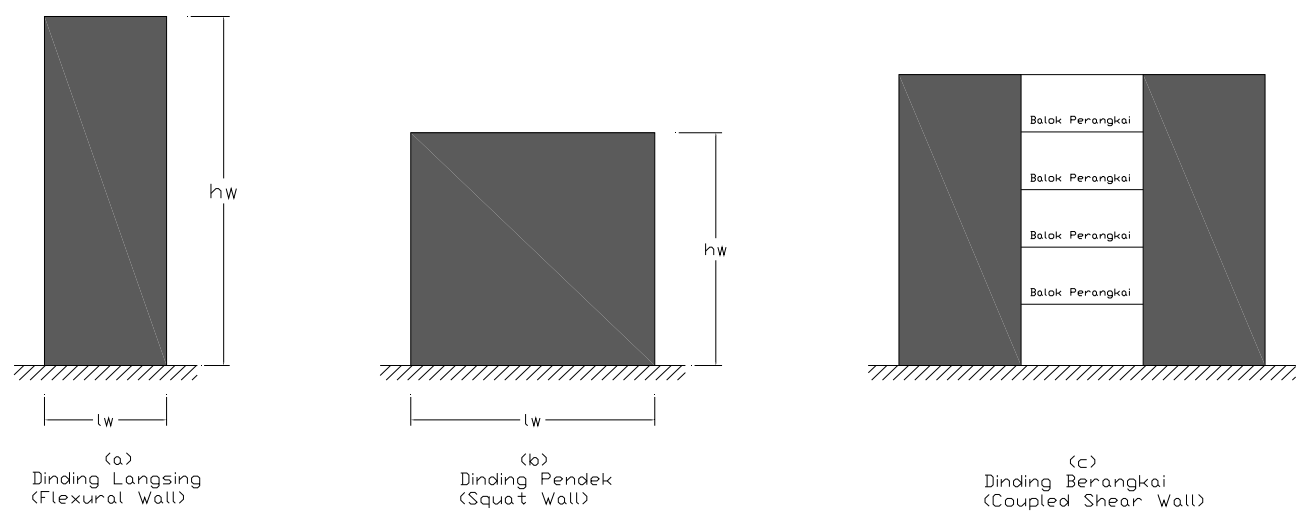

\section{Gambar 1. Kategori Dinding Geser (Tampak Depan).}

Dinding geser beton bertulang kantilever (Gambar 1.a dan 1.b) adalah suatu subsistem struktur gedung yang fungsi utamanya adalah untuk memikul beban geser akibat pengaruh gempa rencana. Kerusakan pada dinding ini hanya boleh terjadi akibat momen lentur (bukan akibat gaya geser), melalui pembentukkan sendi plastis di dasar dinding. Rasio antara tinggi dan lebar dinding geser tidak boleh kurang dari 2 dan lebar tersebut tidak boleh kurang dari 1,5 m. Dinding geser beton bertulang ada dua jenis yaitu dinding geser beton bertulang kantilever daktial penuh dan dinding geser beton bertulang daktial parsial.

Dinding geser beton bertulang berangkai (Gambar 1.c) adalah suatu subsistem struktur gedung yang fungsi utamanya adalah untuk memikul beban geser akibat pengaruh Gempa Rencana, yang terdiri dari dua buah atau lebih dinding geser kantilever yang dirangkaikan satu dengan lainnya oleh balok-balok yang mempunyai perbandingan antara bentang dan tinggi tidak lebih dari 4.

Dinding geser sebagai elemen penahan gaya lateral memiliki keuntungan utama karena menyediakan kontinuitas vertikal pada sistem lateral struktur gedung. Struktur gedung dengan dinding geser sebagai elemen penahan gaya lateral pada umumnya memiliki kinerja yang cukup baik pada saat gempa. Hal ini terbukti dari sedikitnya kegagalan yang terjadi pada sistem struktur dinding geser di kejadian-kejadian gempa yang lalu (Imran, 2008).

\section{STUDI KASUS DAN PEMBAHASAN}

\section{Studi Kasus}

Studi kasus menggunakan dua tipe gedung sekolah 5 lantai, yaitu gedung A dan gedung B yang akan didesain sebagai bagunan tahan gempa. Masing-masing model 
tersebut akan dilakukan penelitian 2 (dua) buah pemodelan yang berbeda, yaitu tipe gedung pertama dinding geser dimodelkan dengan menggunakan fitur wall, sedangkan tipe gedung kedua dinding geser dimodelkan dengan menggunakan fitur kolom ekivalen. Wall merupakan salah satu fitur yang tersedia dalam perangkat lunak ETABS yang digunakan untuk mendisain suatu bangunan gedung tahan gempa dengan fungsi sebagai dinding geser, sedangkan kolom ekivalen dalam hal ini merupakan suatu elemen struktur dengan fitur kolom (frame) pada perangkat lunak ETABS yang ditingkatkan kekakuannya seperti dinding geser.

\section{Data Material dan Data Struktur}

Mutu beton diasumsikan sebesar $25 \mathrm{MPa}$, kemudian mutu baja tulangan utama $400 \mathrm{MPa}$ dan tulangan sengkang $240 \mathrm{MPa}$. Beban yang bekerja adalah berat sendiri struktur, beban hidup $250 \mathrm{~kg} / \mathrm{m}^{2}$, beban mati tambahan $150 \mathrm{~kg} / \mathrm{m}^{2}$, dan beban dinding 250 $\mathrm{kg} / \mathrm{m}^{2}$. Adapun dimensi dan ukuran penampang sebagai berikut:

a. Kolom, menggunakan satu macam kolom, yaitu K1 40x40 cm.

b. Balok, menggunakan tiga macam balok, yaitu B1 ukuran 40x60 cm, B2 ukuran $30 \times 50 \mathrm{~cm}$ dan B3 ukuran 25x40 cm.

c. Dinding Geser, menggunakan satu macam dinding geser, yaitu $W 1$ tebal $30 \mathrm{~cm}$.

d. Pelat, menggunakan satu macam pelat, baik untuk pelat lantai maupun pelat atap, yaitu tebal $13 \mathrm{~cm}$.

Tabel 1. Studi Kasus.

\begin{tabular}{|l|l|l|}
\hline Gedung & \multirow{2}{*}{ Tipe } & Fitur \\
\cline { 3 - 3 } & & Dinding Geser \\
\hline A & A1 & Wall \\
\cline { 2 - 3 } & A2 & Kolom Ekivalen \\
\hline \multirow{2}{*}{ B } & B1 & Wall \\
\cline { 2 - 3 } & B2 & Kolom Ekivalen \\
\hline
\end{tabular}

\section{Data Perencanaan Beban Gempa}

a. Faktor Keutamaan

Kategori gedung termasuk dalam gedung umum yaitu gedung sekoloh, maka Faktor Keutamaan I yang dipakai adalah 1 (Tabel 1 SNI-1726-2002).

b. Respons Spektrum Gempa Rencana

Bangunan terletak di Bandung, wilayah Gempa 3 tanah keras. Berdasarkan SNI1726-2002, pada Tabel 5 nilai $\mathrm{Ca}=0.18$ (percepatan muka tanah Ao), sedangkan untuk nilai $\mathrm{Cv}=0.23$ pada Tabel 6 (spektrum respon gempa rencana Ar). 
c. Faktor Reduksi Gempa

Sistem struktur gedung didiesain sebagai sistem rangka gedung yaitu dinding geser beton bertulang kantilever daktail parsial dengan nilai Faktor Reduksi Gempa 5.5.

d. Kekakuan Struktur

Dalam perencanaan struktur bangunan gedung, pengaruh peretakan beton akan diperhitungkan terhadap kekakuannya dengan cara mengalikan momen inersia penampang unsur struktur dengan persentase efektifitas penampang, untuk kolom dan balok beton bertulang dipakai $75 \%$ sedangkan dinding geser beton bertulang kantilever dipakai 60\% (Pasal 5.5.1 SNI-1726-2002).

e. Kombinasi Pembebanan

Kombinasi pembebanan disain telah ditetapkan menurut Pasal 11.2 SNI 2847.

\section{Asumsi Pemodelan}

Pada penelitian ini, model kolom ekivalen menggunakan analisis pendekatan, yaitu untuk mendapatkan tingkat kekakuan yang cukup (dalam hal ini memiliki kekakuan yang sama dengan model fitur wall), maka pada kolom ekivalen akan dilakukan modifikasi faktor pengali momen inersia penampang.

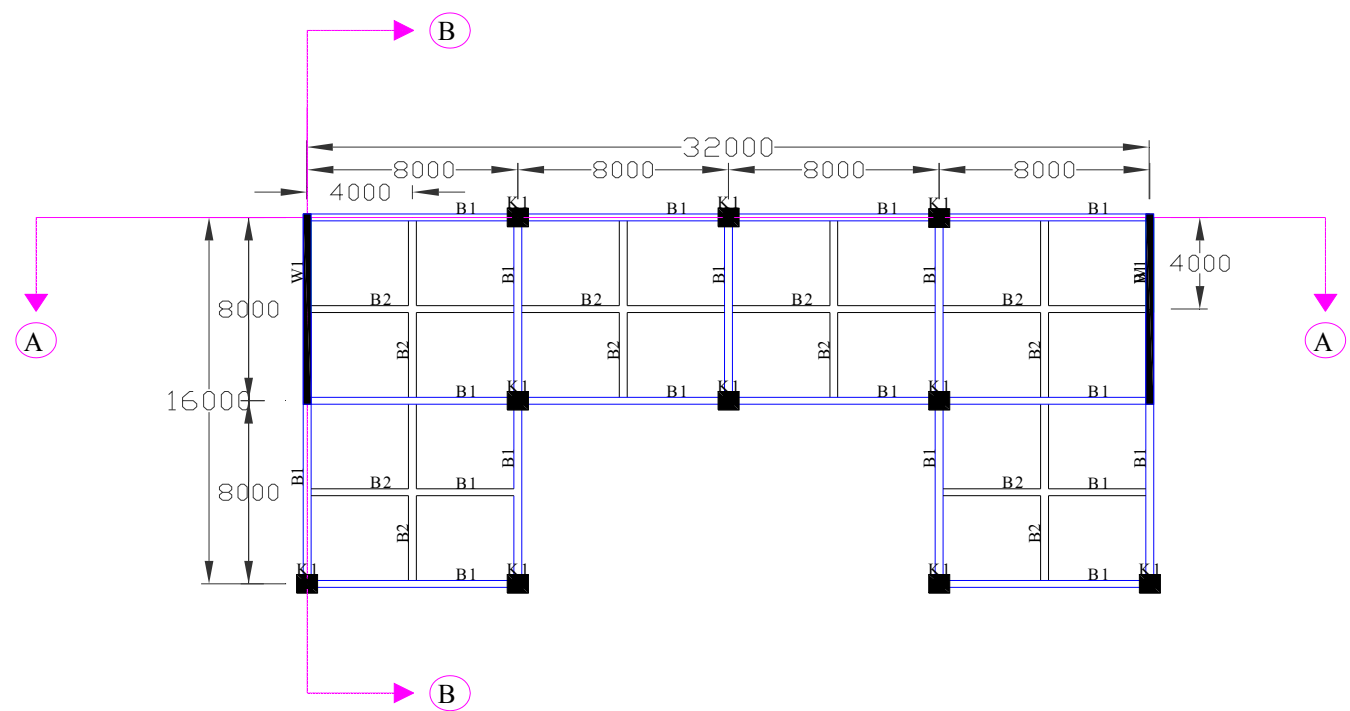

Gambar 1. Denah Balok Kolom dan Dinding Geser Gedung A. 

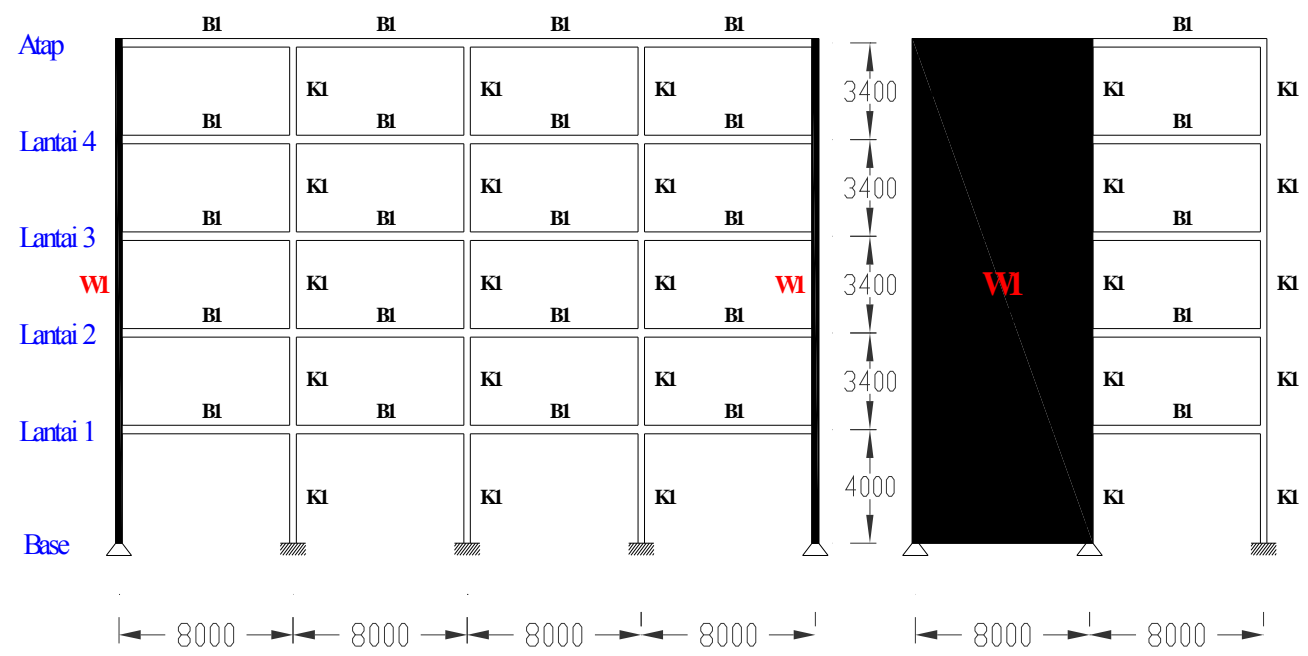

Gambar 2. Pot. Memanjang A - A dan Melintang B - B Gedung A .

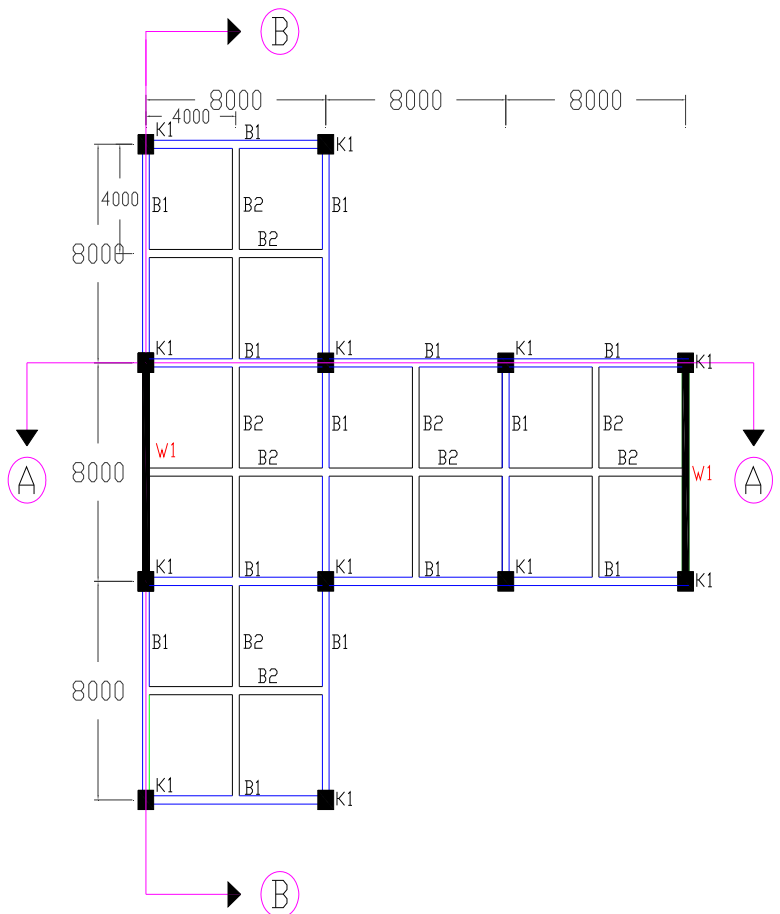

Gambar 3. Denah Balok Kolom dan Dinding Geser Gedung B. 


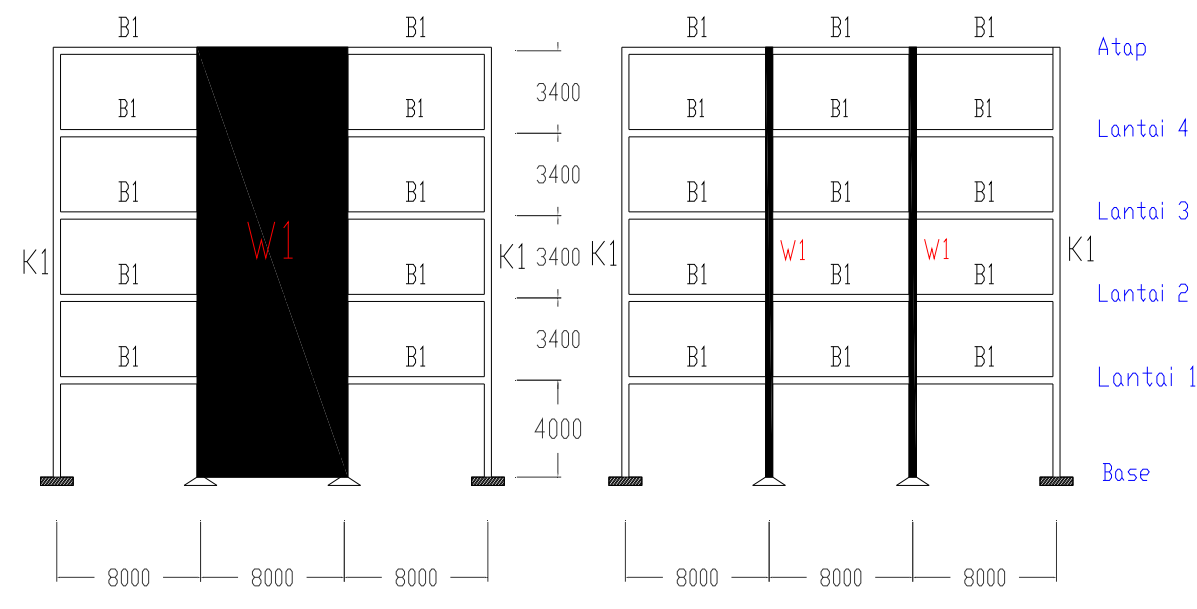

Gambar 4. Pot. Memanjang A - A dan Melintang B - B Gedung B.

\section{Pemodelan Struktur Gedung dengan ETABS}

Masing-masing tipe gedung dimodelkan ke dalam dua model, yaitu model gedung pertama dinding geser dimodelkan sebagai elemen wall dan model gedung kedua dinding geser dimodelkan sebagai kolom ekivalen. Penomoran gedung untuk mempermudah sebagai berikut :

1. Gedung A Model Pertama (A1), adalah gedung A dengan dinding geser dimodelkan sebagai wall.

2. Gedung A Model Kedua (A2), adalah gedung A dengan dinding geser dimodelkan sebagai kolom ekivalen.

3. Gedung B Model Pertama (B1), adalah gedung B dengan dinding geser dimodelkan sebagai wall.

4. Gedung B Model Kedua (B2), adalah gedung B dengan dinding geser dimodelkan sebagai kolom ekivalen.

\section{Pemodelan Struktur Gedung Pertama}

Pada perencanaan gedung model kedua (A2), dinding geser pada gedung akan dimodelkan sebagai elemen kolom ekivalen (Gambar 5). Waktu getar yang paling mendekati gedung A1 adalah dengan menggunakan faktor pengali momen inersia penampang sebesar 15 , faktor pengali ini yang akan dipakai untuk perhitungan gedung A2 selanjutnya. 
Gedung termasuk dalam kategori gedung tidak beraturan. Berdasarkan SNI 1726-2002 pasal 7, pengaruh Gempa Rencana terhadap struktur gedung tidak beraturan ditentukan melalui analisis dinamik respon spektrum. Gambar 6 memperlihatkan bahwa hasil analisis dinamik arah $\mathrm{x}$ pada gedung A1 terjadi peralihan lebih besar dibanding gedung A2, ini memperlihatkan bahwa struktur gedung A2 lebih kaku dibanding struktur gedung A2, artinya faktor pengali momen inersia penampang pada model gedung kolom ekivalen (A2) memberikan pengaruh signifikan pada kekakuan dinding geser.

Dalam hal ini faktor pengali momen inersia penampang hanya ditinjau terhadap waktu getar gedung. Adapun perbedaan \%-relatif peralihan atap arah x antara gedung A1 dan A2 adalah sebesar 7,1370\%.

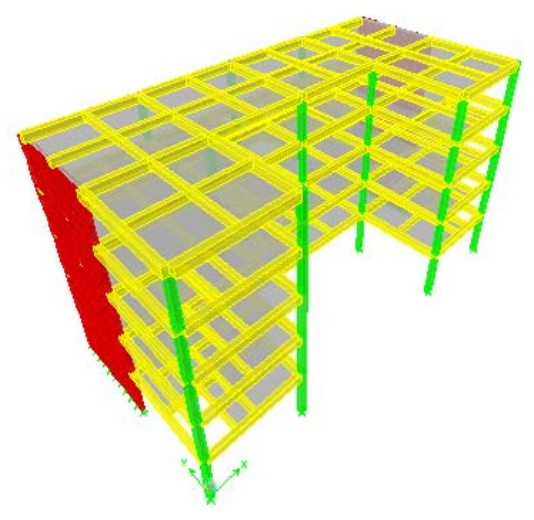

(a). Gedung A1/Wall.

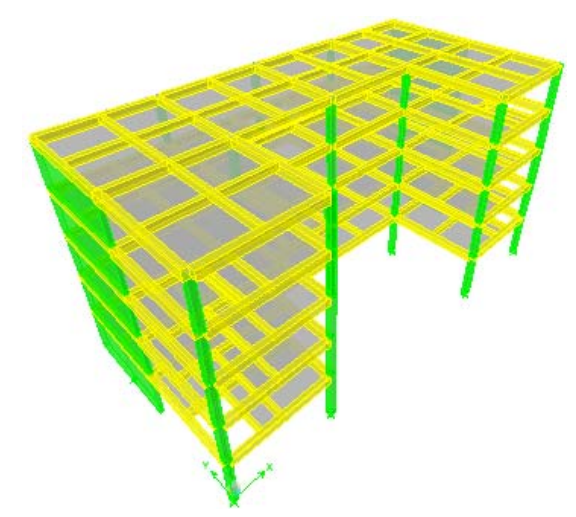

(b). Gedung A2/Kolom Ekivalen.

Gambar 5. Model Gedung Pertama.

Tabel 2. Persen Selisih Waktu Getar Gedung A1 dan A2.

\begin{tabular}{|c|c|c|c|c|}
\hline \multicolumn{2}{|c|}{ A1 } & \multicolumn{2}{c|}{ A2 } & \% Selisih ] \\
\hline $\begin{array}{c}\text { Faktor Pengali } \\
\text { Momen Inersia }\end{array}$ & $\mathrm{T}$ (detik) & $\begin{array}{l}\text { Faktor Pengali } \\
\text { Momen Inersia }\end{array}$ & $\mathrm{T}$ (detik) & \\
\hline \multirow{2}{*}{1} & \multirow{2}{*}{1.8065} & 1 & 1.8782 & 3.9690 \\
\cline { 3 - 5 } & & 10 & 1.8155 & 0.4982 \\
\cline { 3 - 5 } & 15 & 1.8025 & 0.2214 \\
\hline
\end{tabular}

Tabel 3. Persen Selisih Berat Struktur Gedung A1 dan A2.

\begin{tabular}{|c|c|c|}
\hline $\mathrm{A} 1$ & $\mathrm{~A} 2$ & {$[\%$ Selisih $]$} \\
$\mathrm{Wt}(\mathrm{kg})$ & $\mathrm{Wt}(\mathrm{kg})$ & \\
\hline 223539.2652 & 237234.0471 & 6.1263 \\
\hline
\end{tabular}




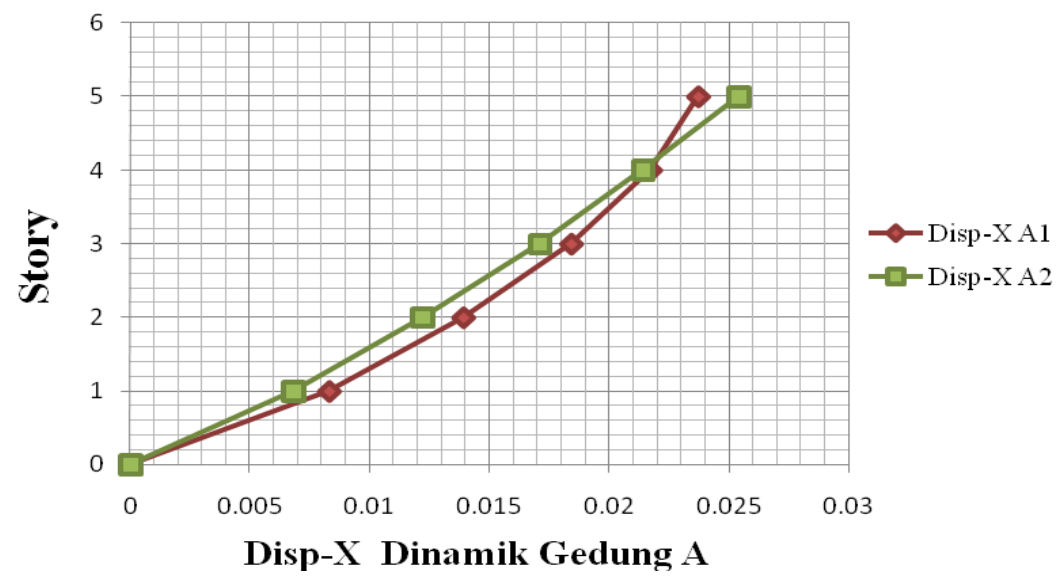

Gambar 6. Grafik Antara Story dan Peralihan Arah x Gedung A.

\section{Pemodelan Struktur Gedung Kedua}

Pada perencanaan gedung model kedua (B2), dinding geser pada gedung akan dimodelkan sebagai elemen kolom ekivalen (Gambar 7). Gambar 8 memperlihatkan bahwa hasil analisis dinamik arah x pada gedung B1 terjadi peralihan lebih kecil dibanding gedung B2, ini memperlihatkan bahwa struktur gedung B1 lebih kaku dibanding struktur gedung B2, artinya faktor pengali momen inersia penampang untuk model gedung kolom ekivalen (B2) tidak memberikan pengaruh signifikan pada kekakuan dinding geser, dalam hal ini faktor pengali momen inersia penampang hanya ditinjau terhadap waktu getar gedung.

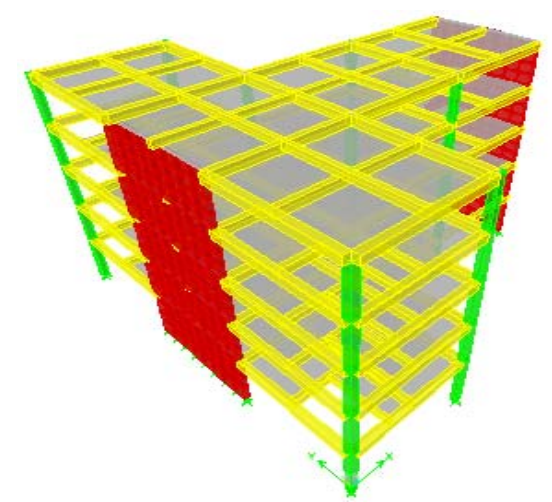

(a). Gedung B1/Wall.

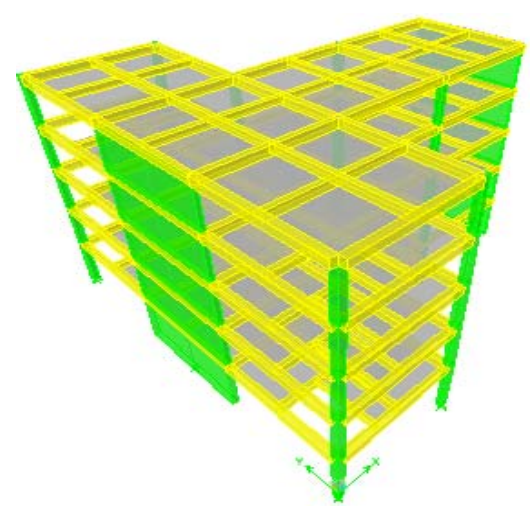

(b). Gedung B2/Kolom Ekivalen.

Gambar 7. Model Gedung Kedua. 
Tabel 4. Persen Selisih Waktu Getar Gedung B1 dan B2.

\begin{tabular}{|c|c|c|c|c|}
\hline \multicolumn{2}{|c|}{ A1 } & \multicolumn{2}{c|}{ A2 } & [ \% Selisih ] \\
\hline $\begin{array}{c}\text { Faktor Pengali } \\
\text { Momen Inersia }\end{array}$ & T (detik) & $\begin{array}{l}\text { Faktor Pengali } \\
\text { Momen Inersia }\end{array}$ & T (detik) & \\
\hline \multirow{2}{*}{1} & \multirow{2}{*}{1.8127} & 1 & 1.9137 & 5.5718 \\
\cline { 3 - 5 } & & 5 & 1.8667 & 2.9790 \\
\cline { 3 - 5 } & 9 & 1.8468 & 1.8812 \\
\hline
\end{tabular}

Tabel 5. Persen Selisih Berat Struktur Gedung B1 dan B2.

\begin{tabular}{|c|c|c|}
\hline $\mathrm{A} 1$ & $\mathrm{~A} 2$ & {$[\%$ Selisih $]$} \\
$\mathrm{Wt}(\mathrm{kg})$ & $\mathrm{Wt}(\mathrm{kg})$ & \\
\hline 198401.6544 & 198346.5667 & 0.0278 \\
\hline
\end{tabular}

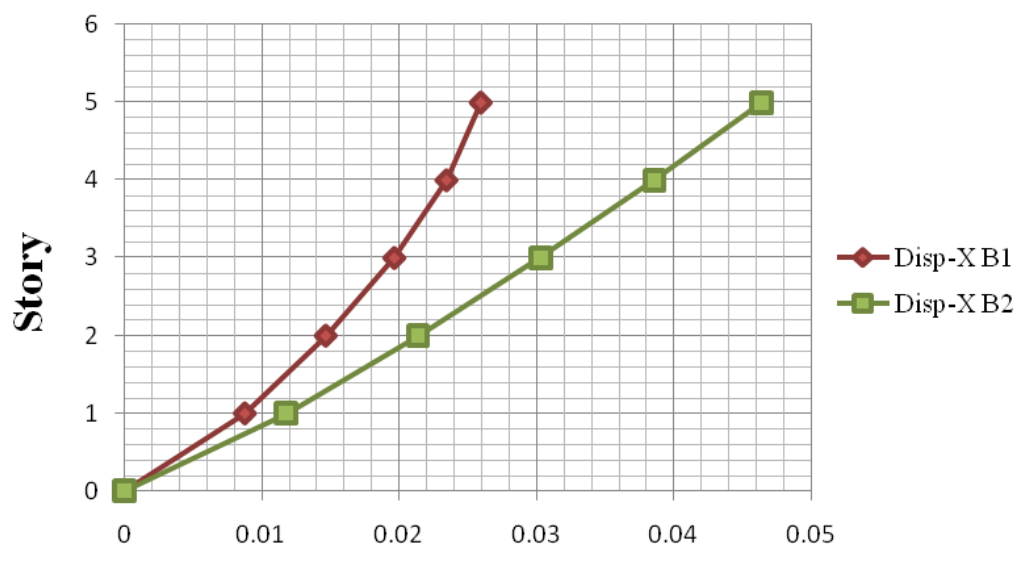

Disp-X Dinamik Gedung B

Gambar 8. Grafik Antara Story dan Peralihan Arah x Gedung B.

\section{KESIMPULAN DAN SARAN}

Kesimpulan yang dapat diambil dari penelitian ini adalah sebagai berikut:

1. Hasil penelitian ini diperoleh faktor pengali penampang momen inersia untuk gedung A yaitu 15, untuk gedung B yaitu 9. Dengan faktor pengali penampang momen inersia tersebut diperoleh hasil waktu getar alami yang hampir sama antara gedung dinding geser yang dimodelkan sebagai kolom ekivalen dengan yang dimodelkan sebagai wall. 
2. Hasil analisis dinamik gedung A yaitu gaya geser dasar sebagai berikut, \%-relatif perbedaan antara gedung A1 dan A2 untuk arah-x sebesar 0,12\%, hasil ini memperlihatkan bahwa pemodelan kolom ekivalen tepat dilakukan untuk arah-x.

3. Hasil analisis dinamik gedung B yaitu gaya geser dasar sebagai berikut, \%-relatif perbedaan antara gedung B1 dan B2 untuk arah-x sebesar 0,57\%, hasil ini memperlihatkan bahwa pemodelan kolom ekivalen tepat dilakukan untuk arah-x.

4. Hasil analisis dinamik gedung A yaitu peralihan atap sebagai berikut, \%-relatif perbedaan antara gedung A1 dan A2 untuk arah-x sebesar 7,17\%, hasil ini memperlihatkan bahwa pemodelan kolom ekivalen tepat dilakukan untuk arah-x.

5. Hasil analisis dinamik gedung B yaitu peralihan atap sebagai berikut, \%-relatif perbedaan antara gedung B1 dan B2 untuk arah-x sebesar 78,46\%, hasil ini memperlihatkan bahwa pemodelan kolom ekivalen tidak tepat dilakukan untuk arah-x.

Sedangkan saran yang dapat disampaikan dari penelitian ini adalah model bangunan gedung dengan dinding geser dimodelkan sebagai kolom ekivalen pada program ETABS dapat dimanfaatkan untuk analisis lebih lanjut, sebagai contoh analisis statik nonlinier atau analisis pushover.

\section{DAFTAR PUSTAKA}

1. American Society of Civil Engineers. (2000). FEMA 356 - Prestandard and Commentary for The Seismic Rehabilation of Buildings, American Society of Civil Engineers, Reston, Virginia.

2. Computer and Structures, Inc. (2007), "ETABS version 8 Manual”, Computer and Structures, Inc., Berkeley, C.A

3. Imran, I Hendrik, F E., Suhelda, Kristianto, A. (2008), "Aplicability Metoda Desain Kapasitas pada Perancangan Struktur Dinding Geser Beton Bertulang”, Seminar HAKI

4. SKBI-1.3.53.1987, Pedoman Perancanaan Pembebanan untuk Rumah dan Gedung, Departemen Pekerjaan Umum.

5. SNI 1726-2002, 2002, Standar Perencanaan Ketahanan Gempa untuk Struktur Bangunan Gedung, Departemen Pemukiman dan Prasarana Wilayah 
6. SNI 03-2847, 2003, Tata Cara Perhitungan Struktur Beton untuk Bangunan Gedung, Jakarta

7. Sukamta, D. (2008), Perencanaan Tahan Gempa Gedung 48 Lantai - Plaza Indonesia II, Seminar HAKI 2008, Hotel Borobudur, Jakarta. 